\title{
Association of serum chloride level alterations with in-hospital mortality
}

\author{
Charat Thongprayoon (D) , Wisit Cheungpasitporn, ${ }^{2}$ Panupong Hansrivijit, ${ }^{3}$ \\ Sorkko Thirunavukkarasu, ${ }^{1}$ Api Chewcharat, ${ }^{1}$ Juan Medaura, ${ }^{2}$ Michael A Mao, ${ }^{4}$ \\ Kianoush Kashani ${ }^{1}$
}

- Additional material is published online only. To view please visit the journal online (http://dx.doi.org/10.1136/ postgradmedj-2019-137270).

'Division of Nephrology and Hypertension, Department of Medicine, Mayo Clinic Rochester, Rochester, Minnesota, USA ${ }^{2}$ Division of Nephrology, Department of Internal Medicine, University of Mississippi Medical Center, Jackson, Mississippi, USA ${ }^{3}$ Department of Internal Medicine, UPMC Pinnacle Harrisburg, Harrisburg, Pennsylvania, USA ${ }^{4}$ Division of Nephrology and Hypertension, Mayo Clinic Florida, Jacksonville, Florida, USA

\section{Correspondence to}

Dr Kianoush Kashani, Mayo Clinic Rochester, Rochester, MN 55905-0002, USA;

kashani.kianoush@mayo.edu

Received 29 October 2019 Revised 4 December 2019 Accepted 16 December 2019 Published Online First 7 January 2020

\section{Check for updates}

\section{(c) Author(s) (or their} employer(s)) 2020. No commercial re-use. See rights and permissions. Published by BMJ.

To cite: Thongprayoon C, Cheungpasitporn W,

Hansrivijit $P$, et al.

Postgrad Med J

2020:96:731-736.

\begin{abstract}
Background We aimed to assess the association between alterations in serum chloride levels during hospitalisation and mortality.
\end{abstract}

Methods We reviewed all adult patients admitted to our hospital from the year 2009 to 2013, who had at least two serum chloride measurements during hospitalisation. The serum chloride change during hospitalisation, defined as the absolute difference between the highest and lowest serum chloride levels, was categorised into seven groups; 0-2, 3-4, 5-6, 7-8, 9-10, 11-12 and $\geq 13 \mathrm{mEq} / \mathrm{L}$. Multivariable logistic regression was performed to assess the independent association between serum chloride change and inhospital mortality, using the serum chloride change of $0-2 \mathrm{mEq} / \mathrm{L}$ as the reference group.

Results A total of 57880 patients, with median serum chloride change of 5 (IQR 3-9) mEq/L, were studied. The in-hospital mortality was progressively increased with larger chloride change, from $0.6 \%$ in group of $0-2$ $\mathrm{mEq} / \mathrm{L}$ to $5.9 \%$ in group of $\geq 13 \mathrm{mEq} / \mathrm{L}(\mathrm{p}<0.001)$. In adjusted analysis, serum chloride change of $\geq 7 \mathrm{mEq} / \mathrm{L}$ was significantly associated with increased in-hospital mortality. For upward trend, serum chloride change of $\geq 3 \mathrm{mEq} / \mathrm{L}$ was significantly associated with increased inhospital mortality, whereas, for downward trend, serum chloride change was not consistently associated with in-hospital mortality.

Conclusion Alterations in serum chloride during hospitalisation were associated with increased hospital mortality. The association was more prominent with upward than downward trend of serum chloride.

\section{BACKGROUND}

Chloride ions are the second most abundant extracellular electrolytes in humans following sodium ions. ${ }^{1}$ Chloride ions play significant roles in acidbase haemostasis of the blood. ${ }^{23}$ Change in chloride levels can be seen in several medical conditions such as fluid overload, congestive heart failure, as well as renal, endocrine and metabolic disorders. ${ }^{4}$

The recent data suggest an association between change in serum chloride levels and elevated mortality. ${ }^{5-8}$ However, most of these studies were reported in critically ill patients. ${ }^{79}$ An increase in serum chloride level by chloride-rich fluids can result in hyperchloremic metabolic acidosis, associated with poor outcomes in intensive care unit (ICU) patients, especially those with severe sepsis and septic shock. ${ }^{9-12}$ A recent large retrospective analysis of 18825 patients demonstrated that an increase in serum chloride levels within 72 hours after ICU admission by $1 \mathrm{mmol} / \mathrm{L}$ was associated with $8 \%$ increased risk of 30 -day mortality. ${ }^{7}$

The information on the effects of serum chloride level alterations on the clinical outcomes among hospitalised patients is scarce. Thus, we conducted this retrospective study to elaborate on the association between serum chloride change and hospital mortality.

\section{MATERIAL AND METHODS Study population}

We searched the patient database to identify all adult patients admitted to Mayo Clinic Hospital, Rochester, Minnesota, from 1 January 2009 to 31 December 2013. Patients with at least two serum chloride measurements during hospital stay were included. Patients without research authorisation were excluded. If patients had recurring admissions, only the first hospitalisation during the study period was included in the analysis.

\section{Data collection}

Clinical information and laboratory data were obtained from Mayo Clinic's institutional electronic health record system using the Mayo Clinic Life Science System Database. This database contains demographic characteristics, hospital admission information, diagnosis and procedure codes, laboratory test results and flow sheet data of inpatient admission. Serum chloride change during hospitalisation, defined as the absolute difference between the highest and lowest serum chloride during the hospital stay, was the exposure of interest. Serum chloride change was categorised into seven groups; $0-2,3-4,5-6,7-8,9-10,11-12$ and $\geq 13 \mathrm{mEq} / \mathrm{L}$.

To further assess if the direction of serum chloride change was associated with patient outcomes, the timing of the highest serum chloride in relation to the lowest serum chloride was determined. If the highest serum chloride occurred before the lowest serum chloride, a downward trend of serum chloride change was assumed, and negative values for serum chloride change (the lowest-the highest serum chloride) were assigned. In contrast, if the highest serum chloride occurred after the lowest serum chloride, the upward trend of serum chloride change was assumed, and positive values for serum chloride change (the highest-the lowest serum chloride) were assigned. Chloride alterations with direction of change were categorised into 14 groups; $\leq-13,-12$ to $-11,-10$ to $-9,-8$ to $-7,-6$ 
to $-5,-4$ to $-3,-2$ to 0,1 to 2,3 to 4,5 to 6,7 to 8,9 to 10,11 to $12, \geq 13 \mathrm{mEq} / \mathrm{L}$.

Principal diagnoses were grouped based on the International Classification of Diseases, ninth revision codes. The Charlson comorbidity index ${ }^{13}$ was calculated to assess comorbid conditions at the time of admission. The comorbid conditions were determined using a previously validated data abstraction algorithm. ${ }^{14}$ The baseline estimated glomerular filtration rate (eGFR) was calculated based on age, sex, race and serum creatinine, using the chronic kidney disease epidemiology collaboration equation. ${ }^{15}$ Acute kidney injury (AKI) was defined as an increase in serum creatinine of $\geq 0.3 \mathrm{mg} / \mathrm{dL}$ or $\geq 1.5$ times baseline value. ${ }^{16}$

In-hospital mortality was the outcome of interest. Death status was obtained from the institutional database.

\section{Statistical analysis}

Continuous variables were presented as mean \pm SD or median with IQR, as appropriate. The differences in continuous variables between chloride change groups were tested using analysis of variance for parametric or Kruskal-Wallis test for nonparametric test. Categorical variables were presented as count with percentage. The differences in categorical variables between chloride change groups were tested using the Chi-squared test. Logistic regression analysis was performed to assess the association between serum chloride change during hospitalisation and in-hospital mortality. The serum chloride change group of $0-2$ $\mathrm{mEq} / \mathrm{L}$ was selected as the reference group for outcome comparison. Several models were built to adjust for priori-defined variables. Model 1 was unadjusted; model 2 was adjusted for age, sex, race, principal diagnosis, Charlson comorbidity index, history of coronary artery disease, congestive heart failure, peripheral artery disease, stroke, diabetes mellitus, chronic obstructive pulmonary disease, cirrhosis, eGFR, AKI occurrence in hospital, the number of serum chloride measurements during hospitalisation and length of hospital stay; model 3 was adjusted for all variables in model 2, plus the index admission serum chloride; model 4 was adjusted for all variables in model 2 , plus the lowest chloride during hospitalisation, and model 5 was adjusted for all variables in model 2, plus the highest chloride. A restricted cubic spline was constructed to demonstrate the non-linear association between serum chloride change with its direction and in-hospital mortality, using STATA (STATACorp LLC). Thirteen knots were placed at $-12,-10,-8,-6,-2,0,2,4,6,8,10$ and 12 of serum chloride change. A similar analysis was performed

Table 1 Baseline clinical characteristics

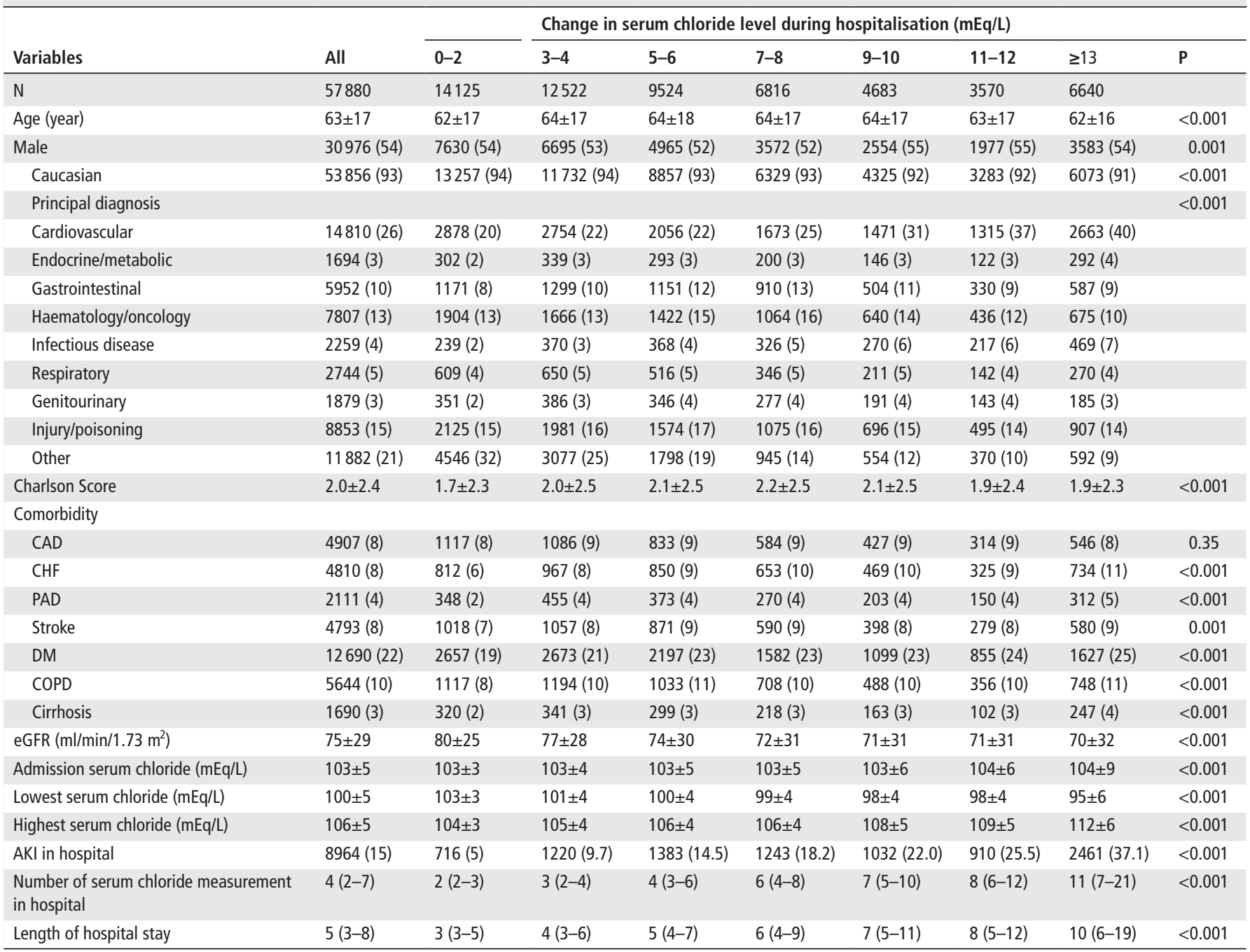

Continuous data are presented as mean \pm SD or median (IQR) as appropriate; categorical data are presented as count (\%).

$A K I$, acute kidney injury; CAD, coronary artery disease; CHF, congestive heart failure; COPD, chronic obstructive pulmonary disease; DM, diabetes mellitus; eGFR, estimated glomerular filtration rate; $P A D$, peripheral artery disease. 
Table 2 The association between serum chloride change and in-hospital mortality

\begin{tabular}{|c|c|c|c|c|c|c|c|c|}
\hline \multirow[b]{2}{*}{ Outcome } & \multicolumn{8}{|c|}{ Change in serum chloride level during hospitalisation (mEq/L) } \\
\hline & $0-2$ & $3-4$ & $5-6$ & $7-8$ & $9-10$ & $11-12$ & $\geq 13$ & $P$ trend \\
\hline Hospital mortality & $77(0.6)$ & $101(0.8)$ & $106(1.1)$ & $97(1.4)$ & $104(2.2)$ & $99(2.8)$ & $389(5.9)$ & $<0.001$ \\
\hline \multicolumn{9}{|l|}{ Mortality, OR (95\% Cl) } \\
\hline Model 1: unadjusted & 1 (ref) & $\begin{array}{l}1.48 \\
\text { (1.10 to } 2.00)\end{array}$ & $\begin{array}{l}2.05 \\
\text { (1.53 to } 2.76)\end{array}$ & $\begin{array}{l}2.63 \\
\text { (1.95 to } 3.56)\end{array}$ & $\begin{array}{l}4.14 \\
\text { (3.08 to } 5.57)\end{array}$ & $\begin{array}{l}5.20 \\
\text { (3.85 to } 7.02)\end{array}$ & $\begin{array}{l}11.35 \\
\text { (8.87 to } 14.52)\end{array}$ & $<0.001$ \\
\hline Model $2^{*}$ & 1 (ref) & $\begin{array}{l}1.12 \\
\text { (0.83 to } 1.51)\end{array}$ & $\begin{array}{l}1.26 \\
\text { (0.93 to } 1.70)\end{array}$ & $\begin{array}{l}1.41 \\
\text { (1.04 to } 1.93)\end{array}$ & $\begin{array}{l}2.05 \\
(1.51 \text { to } 2.80)\end{array}$ & $\begin{array}{l}2.46 \\
\text { (1.79 to } 3.37)\end{array}$ & $\begin{array}{l}3.52 \\
\text { (2.66 to } 4.66)\end{array}$ & $<0.001$ \\
\hline $\begin{array}{l}\text { Model 3: model 2, and } \\
\text { admission serum chloride }\end{array}$ & 1 (ref) & $\begin{array}{l}1.12 \\
\text { (0.83 to } 1.51)\end{array}$ & $\begin{array}{l}1.25 \\
\text { (0.93 to } 1.69)\end{array}$ & $\begin{array}{l}1.41 \\
\text { (1.03 to } 1.92)\end{array}$ & $\begin{array}{l}2.05 \\
\text { (1.51 to } 2.79)\end{array}$ & $\begin{array}{l}2.46 \\
\text { (1.79 to } 3.37)\end{array}$ & $\begin{array}{l}3.52 \\
(2.66 \text { to } 4.66)\end{array}$ & $<0.001$ \\
\hline $\begin{array}{l}\text { Model 4: model 2, and lowest } \\
\text { serum chloride }\end{array}$ & 1 (ref) & $\begin{array}{l}1.19 \\
(0.88 \text { to } 1.61)\end{array}$ & $\begin{array}{l}1.41 \\
\text { (1.04 to } 1.90)\end{array}$ & $\begin{array}{l}1.66 \\
\text { (1.21 to } 2.26)\end{array}$ & $\begin{array}{l}2.47 \\
(1.80 \text { to } 3.37)\end{array}$ & $\begin{array}{l}3.07 \\
\text { (2.22 to } 4.23)\end{array}$ & $\begin{array}{l}4.94 \\
\text { (3.69 to } 6.63 \text { ) }\end{array}$ & $<0.001$ \\
\hline $\begin{array}{l}\text { Model } 5 \text { : model } 2 \text {, and highest } \\
\text { serum chloride }\end{array}$ & 1 (ref) & $\begin{array}{l}1.06 \\
\text { (0.79 to } 1.44)\end{array}$ & $\begin{array}{l}1.13 \\
\text { (0.83 to } 1.53)\end{array}$ & $\begin{array}{l}1.20 \\
\text { (0.88 to } 1.64)\end{array}$ & $\begin{array}{l}1.61 \\
\text { (1.18 to } 2.20)\end{array}$ & $\begin{array}{l}1.81 \\
(1.31 \text { to } 2.50)\end{array}$ & $\begin{array}{l}2.15 \\
\text { (1.59 to } 2.92)\end{array}$ & $<0.001$ \\
\hline
\end{tabular}

*Adjusted for age, sex, race, principal diagnosis, Charlson comorbidity score, history of coronary artery disease, congestive heart failure, peripheral artery disease, stroke, diabetes mellitus, chronic obstructive pulmonary disease, cirrhosis, eGFR, acute kidney injury, number of serum chloride measurement during hospitalisation, and length of stay. eGFR, estimated glomerular filtration rate.

to assess the association between serum chloride change with its direction and in-hospital mortality. The serum chloride change group from -2 to $0 \mathrm{mEq} / \mathrm{L}$ was selected as the reference group for outcome comparison. Subgroup analysis was performed in patients with serum chloride within the normal range (96-108 $\mathrm{mEq} / \mathrm{L}$ ) during hospitalisation. Two-tailed $\mathrm{p}$ value $<0.05$ was considered statistically significant. All analyses were performed using JMP statistical software V.10 (SAS Institute).

\section{RESULT}

\section{Clinical characteristics}

A total of 57880 eligible patients were included in the study. Fifty-four per cent of enrolled patients were male. The mean age was $63 \pm 17$ years. The median number of serum chloride measurements during hospitalisation was $4(2-5)$, and the length of hospital stay was 5 (3-8) days. The mean admission serum chloride was $103 \pm 5 \mathrm{mEq} / \mathrm{L}$. The median serum chloride change during hospitalisation was 5 (IQR 3-9) mEq/L. 24\%, 22\%, 16\%, $12 \%, 8 \%, 6 \%$ and $11 \%$ had chloride change of $0-2,3-4,5-6$, 7-8, 9-10, 11-12 and $\geq 13 \mathrm{mEq} / \mathrm{L}$, respectively. The clinical characteristics of patients based on serum calcium change groups were summarised in table 1 .

\section{Serum chloride change and in-hospital mortality}

Out of 57880 patients included in the study, 973 (1.7\%) died in the hospital. The in-hospital mortality was progressively increased with greater chloride change, from $0.6 \%$ in group of $0-2 \mathrm{mEq} / \mathrm{L}$ to $5.9 \%$ in the group of $\geq 13 \mathrm{mEq} / \mathrm{L}$ ( $\mathrm{p}$ for trend $<0.001$ ) (table 2). When adjusting for potential confounders (model 2), serum chloride change of 7-8, 9-10, 11-12 and $\geq 13 \mathrm{mEq} / \mathrm{L}$ was significantly associated with increased in-hospital mortality with adjusted OR of 1.41 (95\% CI 1.03 to 1.93 ), 2.05 (95\% CI 1.51 to 2.80$), 2.46$ (95\% CI 1.79 to 3.37 ) and 3.52 (95\% CI 2.66 to 4.66), respectively, when compared with serum chloride change group of $0-2 \mathrm{mEq} / \mathrm{L}$. The association remained statistically significant when further adjustments were implemented for the admission serum chloride level (mean $103 \pm 5 \mathrm{mEq} / \mathrm{L})$ (model 3 ). When further adjustments for the lowest serum chloride (mean $100 \pm 5 \mathrm{mEq} / \mathrm{L}$ ) were considered (model 4 ), serum chloride change of $\geq 5 \mathrm{mEq} / \mathrm{L}$ was significantly associated with increased in-hospital mortality. After accounting for the highest serum chloride (mean $106 \pm 5 \mathrm{mEq} / \mathrm{L}$ ) (model 5 ), serum chloride change of $\geq 9-10 \mathrm{mEq} / \mathrm{L}$ was significantly associated with increased in-hospital mortality. The subgroup analysis of patients with serum chloride within the normal range during hospitalisation consistently showed that the greater extent of serum chloride change was significantly associated with increased in-hospital mortality (online supplementary table S1)

\section{Direction of serum chloride change and in-hospital mortality}

The lowest in-hospital mortality was observed in patients with serum chloride change from -2 to $0 \mathrm{mEq} / \mathrm{L}$. Higher in-hospital mortality rates were observed in both downward and upward trend of serum chloride change (table 3 , and figure 1 ). The association between the downward trend of serum chloride change varied across the adjusted models. In models 2 and 4 (additionally adjusting for the lowest serum chloride), serum chloride change of $\leq-9 \mathrm{mEq} / \mathrm{L}$ was associated with increased in-hospital mortality. In model 3 (additionally adjusting for the admission serum chloride), only serum chloride change of $\leq-13 \mathrm{mEq} / \mathrm{L}$ was associated with increased in-hospital mortality. In model 5 (additionally adjusting for the highest serum chloride), the downward trend of serum chloride change regardless of the degree was not significantly associated with increased in-hospital mortality.

The association between the upward trajectory of serum chloride level was consistent across the adjusted models. Serum chloride change of $\geq 3 \mathrm{mEq} / \mathrm{L}$ was significantly associated with increased in-hospital mortality in all adjusted models. The OR of in-hospital mortality associated with the upward trend of serum chloride change was higher than the OR of in-hospital mortality associated with the downward trend of serum chloride change. Similar results were observed in the subgroup analysis of patients with serum chloride within the normal range during hospitalisation (online supplementary table S2).

\section{DISCUSSION}

In this study, we reported an association between in-hospital mortality and increased serum chloride alterations regardless of the principal diagnosis and comorbid conditions. While the upward trend of serum chloride change was significantly associated with increased in-hospital mortality, the downward trend of serum chloride change was not consistently associated with in-hospital mortality.

Chloride ions are engaged in many physiological processes, including blood pressure, acid-base balance and glomerular 
Table 3 The association between the direction of serum chloride change and in-hospital mortality

\begin{tabular}{llllllll}
\hline Chloride change $(\mathbf{m E q} / \mathbf{L})$ & $\mathbf{N}$ & In-hospital mortality & Model 1 & Model 2 & Model 3 & Model 4 & Model 5 \\
\hline$\leq-13$ & 4394 & $134(3.1)$ & $6.83(4.75-9.81)$ & $1.92(1.29-2.85)$ & $1.66(1.12-2.48)$ & $2.77(1.85-4.15)$ & $1.13(0.75-1.71)$ \\
\hline-12 to -11 & 2304 & $34(1.5)$ & $3.25(2.04-5.18)$ & $1.63(1.01-2.62)$ & $1.46(0.90-2.35)$ & $2.07(1.28-3.34)$ & $1.16(0.72-1.89)$ \\
-10 to -9 & 2795 & $40(1.4)$ & $3.15(2.02-4.92)$ & $1.64(1.04-2.59)$ & $1.51(0.96-2.39)$ & $2.01(1.27-3.18)$ & $1.27(0.80-2.00)$ \\
\hline-8 to -7 & 3730 & $38(1.0)$ & $2.23(1.42-3.51)$ & $1.19(0.75-1.89)$ & $1.14(0.72-1.81)$ & $1.44(0.91-2.28)$ & $1.01(0.64-1.60)$ \\
-6 to -5 & 4971 & $33(0.7)$ & $1.45(0.91-2.32)$ & $0.91(0.56-1.46)$ & $0.88(0.55-1.41)$ & $1.03(0.64-1.66)$ & $0.81(0.50-1.30)$ \\
-4 to -3 & 6477 & $39(0.6)$ & $1.31(0.84-2.06)$ & $1.00(0.63-1.56)$ & $0.98(0.62-1.54)$ & $1.08(0.69-1.70)$ & $0.94(0.60-1.48)$ \\
-2 to 0 & 8285 & $38(0.5)$ & $1($ ref) & $1($ ref) & $1($ ref) & $1($ ref) & 1 (ref) \\
1 to 2 & 5840 & $39(0.7)$ & $1.46(0.93-2.28)$ & $1.39(0.88-2.18)$ & $1.46(0.93-2.28)$ & $1.41(0.90-2.21)$ & $1.37(0.88-2.16)$ \\
\hline 3 to 4 & 6045 & $62(1.0)$ & $2.25(1.50-3.37)$ & $1.62(1.07-2.44)$ & $1.75(1.16-2.64)$ & $1.75(1.16-2.64)$ & $1.53(1.02-2.31)$ \\
\hline 5 to 6 & 4553 & $73(1.6)$ & $3.54(2.39-5.24)$ & $2.04(1.37-3.05)$ & $2.26(1.51-3.38)$ & $2.34(1.57-3.50)$ & $1.83(1.22-2.74)$ \\
7 to 8 & 3086 & $59(1.9)$ & $4.23(2.81-6.37)$ & $2.16(1.42-3.28)$ & $2.45(1.61-3.74)$ & $2.59(1.70-3.95)$ & $1.81(1.19-2.76)$ \\
9 to 10 & 1888 & $64(3.4)$ & $7.61(5.08-11.41)$ & $3.26(2.15-4.95)$ & $3.74(2.45-5.70)$ & $4.06(2.66-6.19)$ & $2.55(1.67-3.89)$ \\
11 to 12 & 1266 & $65(5.1)$ & $11.75(7.84-17.61)$ & $4.48(2.94-6.84)$ & $5.29(3.45-8.11)$ & $5.92(3.85-9.09)$ & $3.34(2.17-5.13)$ \\
$\geq 13$ & 2246 & $255(11.4)$ & $27.80(19.70-39.22)$ & $7.81(5.38-11.32)$ & $9.89(6.77-14.45)$ & $11.88(8.09-17.45)$ & $4.82(3.27-7.12)$ \\
\hline
\end{tabular}

Model 1: unadjusted.

Model 2: Adjusted for age, sex, race, principal diagnosis, Charlson comorbidity score, history of coronary artery disease, congestive heart failure, peripheral artery disease, stroke, diabetes mellitus, chronic obstructive pulmonary disease, cirrhosis, eGFR, acute kidney injury, the number of serum chloride measurement during hospitalisation and length of stay.

Model 3: model 2 and the admission serum chloride.

Model 4: model 2 and the lowest serum chloride.

Model 5: model 2 and the highest serum chloride.

eGFR, estimated glomerular filtration rate.

filtration pressure regulation. ${ }^{17}{ }^{18}$ Some data suggest that chloride may be associated with hypertension. For example among patients with Gordon's syndrome pseudohypoaldosteronism type II are hypertensive while the main defect is increased chloride reabsorption from the distal convoluted tubules. ${ }^{19}$ In animal models of hypertension, only sodium loading that is accompanied by chloride can increase blood pressure and while other sources of sodium loading only result in sodium retention and renin-angiotensin-aldosterone system suppression. ${ }^{20}$ Chloride also could increase blood pressure by directly acting on the vascular smooth muscle cells. ${ }^{21}$ High chloride concentration in the distal loop of Henle leads to tubular-glomerular feedback by chloride sensing mechanisms in the macula densa. ${ }^{1}$ This feedback results in renal afferent vasoconstriction and reduced glomerular filtration. $^{22} 23$

A decrease in serum chloride may happen when total body chloride is depleted (ie, extrarenal loss in vomiting, bowel fistulas, nasogastric drainage, or burns, and also renal loss in diuretic use and salt-losing nephropathies) or diluted (ie,

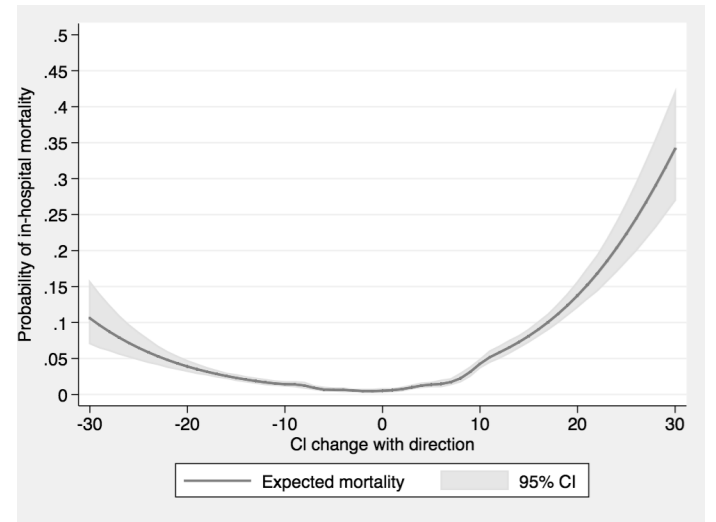

Figure 1 The restricted cubic spline demonstrated the association between the direction of serum chloride change and in-hospital mortality. hypothyroidism, hyperglycaemia, syndrome of inappropriate antidiuretic hormone secretion (SIADH), or use of drug including barbiturates and chlorpropamide, or edematous states including heart failure, cirrhosis and nephrotic syndrome). ${ }^{424} 25$ Serum chloride can also decrease in setting of compensated respiratory acidosis and metabolic alkalosis. ${ }^{26-28}$ The main pathophysiology mechanisms for an increase in serum chloride include loss of electrolyte free water (ie, skin loss in fever and hypercatabolic states, inadequate water intake or renal losses in diabetes insipidus), loss of hypotonic fluids (ie, extrarenal in diarrhoea and burn or renal in osmotic diuresis, diuretic use or intrinsic kidney diseases), sodium gain (ie, salt-water drowning, hypertonic or large volume normal saline), non-anion gap metabolic acidosis (ie, renal tubular acidosis, small bowel diarrhoea, ureteral diversion, early AKI, primary hyperparathyroidism or during recovery from diabetic ketoacidosis) and compensated respiratory alkalosis. ${ }^{24}$ Similar to previous reports, we observed that the upward trajectory of serum chloride change could be significantly associated with increased in-hospital mortality. ${ }^{29-31}$ In contrast, although the downward trajectory of serum chloride might be associated with increased in-hospital mortality when serum chloride change was $\leq-9 \mathrm{mEq} / \mathrm{L}$, the association was not consistently observed in all adjusted analysis.

Among general hospitalised patients, after adjusting for potential confounders, we demonstrated that only upward trend of serum chloride change was significantly associated with increased in-hospital mortality. An increase in serum chloride levels indicates the presence or development of normal anion gap metabolic acidosis or the use of chloride-rich infusion (eg, intravenous normal saline $0.9 \%$ solutions for large-volume fluid resuscitation). ${ }^{32-36}$ Recently, among critically ill patients, a pragmatic, cluster-randomised, multiple-crossover trial of 15802 patients in a single-centre demonstrated that the patients who received intravenous fluid resuscitation with balanced crystalloids had lower major adverse kidney events (ie, higher survival and lower rate of renal-replacement therapy, and chronic kidney disease development) than those who received intravenous saline. ${ }^{36}$ 
Among non-ICU adult patients, another single-centre, pragmatic, multiple-crossover trial of 13347 patients demonstrated that intravenous fluids (balanced crystalloids vs normal saline) in the emergency department found no difference in mortality (at hospital discharge or 30 days) among two groups. ${ }^{37}$ However, the investigators reported significantly similar lowering in major adverse kidney events within 30 days when patients received balanced crystalloids versus normal saline. ${ }^{37}$ While this study demonstrated increase in serum chloride within 24 hours after emergency department arrival among those who received saline than those who received balanced crystalloids, the differences among chloride levels among two groups decreased in 72 hours and the data on chloride change during hospitalisation were limited. ${ }^{37}$ While the data on type of fluid utilisation were limited in our large cohort study, with available information on serum chloride levels during hospitalisation, we were able to find that the upward trajectory of serum chloride levels of $\geq 3 \mathrm{mEq} / \mathrm{L}$ was significantly associated with increased in-hospital mortality in all models.

This study has several limitations. This is a single-centre retrospective cohort study. Hence, a causal relationship between serum chloride change and death could not be definitely established. This study included all hospitalised patients. Therefore, the included patient population was quite heterogeneous. In addition, the data from this study were retrieved from the institutional database. Unfortunately, some clinical information such as fluid balance, the use of intravenous fluid and diuretics, was not available in our database, and, therefore, we were not able to report them. Although we extensively adjusted for potential confounders, the association between serum chloride change and mortality could have remained confounded by unmeasured or unknown factors. In addition, our study did not account for change in serum sodium (due to collinearity with change in

\section{Main messages}

- The greater alteration in serum chloride during hospitalisation was associated with increased in-hospital mortality.

- The upward trend of serum chloride change was significantly associated with increased in-hospital mortality.

- The association of the downward trend of serum chloride change and in-hospital was less prominent, and not consistent among different analyses.

\section{Current research questions}

- The association between change in serum chloride in other patient population, for example critically ill patients or surgical patients.

- The impact of serum chloride change on other patient outcomes, for example acute kidney injury or long-term mortality.

- The impact of acuity, variability and fluctuation of serum chloride change on patient outcomes.

\section{What is already known on the subject}

- Admission serum chloride is associated with mortality in hospitalised patients. serum chloride) and acid-base status (due to the missing data of arterial blood gas) in the analysis despite a potential interaction between serum chloride, serum sodium and acid-base status on patient outcomes. Future research in more homogenous patient population, such as critically ill or surgical patients, with use of more comprehensive clinical information may be needed to confirm this reported association. Finally, our investigation only addresses the impact of magnitude and direction of serum chloride change on in-hospital mortality, but other aspects of serum chloride change, such as acuity and variability, and the impact on other patient outcomes, such as AKI or long-term mortality, were not assessed. These factors are also important to the understanding of the relationship between serum chloride change with patient outcomes. The assessment of the trajectory of serum chloride during hospitalisation should be performed in future studies.

In conclusion, we demonstrated that regardless of principal diagnosis and comorbid conditions, patients with greater chloride change particularly on the upward trajectory during hospitalisation had higher mortality.

Contributors $\mathrm{CT}, \mathrm{WC}$, and $\mathrm{KK}$ originated research idea. $\mathrm{CT}$ and $\mathrm{WC}$ designed the study. CT, WC, PH, ST, AC, JM and MAM collected data. CT analysed data. CT, WC and PH wrote manuscript. ST, AC, JM, MAM and KBK edited manuscript. KK supervised the study.

Funding The authors have not declared a specific grant for this research from any funding agency in the public, commercial or not-for-profit sectors.

Competing interests None declared.

Patient consent for publication Not required.

Ethics approval The Mayo Clinic Institutional Review Board approved this study (IRB number 15-000024).

Provenance and peer review Not commissioned; externally peer reviewed.

Data availability statement Data are available upon reasonable request.

\section{ORCID iD}

Charat Thongprayoon http://orcid.org/0000-0002-8313-3604

\section{REFERENCES}

1 Berend K, van Hulsteijn LH, Gans ROB. Chloride: the Queen of electrolytes? Eur J Intern Med 2012;23:203-11.

2 Havlin J, Matousovic K, Schück O. Sodium-Chloride Difference as a Simple Parameter for Acid-Base Status Assessment. Am J Kidney Dis 2017;69:707-8.

3 Moviat M, van den Boogaard M, Intven F, et al. Stewart analysis of apparently normal acid-base state in the critically ill. J Crit Care 2013;28:1048-54.

4 Yunos Nor'azim Mohd, Bellomo R, Story D, et al. Bench-to-bedside review: chloride in critical illness. Crit Care 2010;14:226.

5 Grodin JL, Simon J, Hachamovitch R, et al. Prognostic role of serum chloride levels in acute decompensated heart failure. J Am Coll Cardiol 2015;66:659-66.

6 Testani JM, Hanberg JS, Arroyo JP, et al. Hypochloraemia is strongly and independently associated with mortality in patients with chronic heart failure. Eur J Heart Fail 2016;18:660-8.

7 Kim HJ, Oh TK, Song I-A, et al. Association between fluctuations in serum chloride levels and 30-day mortality among critically ill patients: a retrospective analysis. BMC Anesthesiol 2019;19:79.

8 McCallum L, Jeemon P, Hastie CE, et al. Serum chloride is an independent predictor of mortality in hypertensive patients. Hypertension 2013;62:836-43

$9 \mathrm{Oh} \mathrm{HJ}, \mathrm{Kim}$ SJ, Kim YC, et al. An increased chloride level in hypochloremia is associated with decreased mortality in patients with severe sepsis or septic shock. Sci Rep 2017;7:15883.

10 Neyra JA, Canepa-Escaro F, Li X, et al. Association of Hyperchloremia with hospital mortality in critically ill septic patients. Crit Care Med 2015;43:1938-44.

11 O'Dell E, Tibby SM, Durward A, et al. Hyperchloremia is the dominant cause of metabolic acidosis in the postresuscitation phase of pediatric meningococcal sepsis*. Crit Care Med 2007;35:2390-4.

12 Noritomi DT, Soriano FG, Kellum JA, et al. Metabolic acidosis in patients with severe sepsis and septic shock: a longitudinal quantitative study. Crit Care Med 2009;37:2733-9.

13 Charlson M, Szatrowski TP, Peterson J, et al. Validation of a combined comorbidity index. J Clin Epidemiol 1994;47:1245-51. 
14 Singh B, Singh A, Ahmed A, et al. Derivation and validation of automated electronic search strategies to extract Charlson comorbidities from electronic medical records. Mayo Clin Proc 2012;87:817-24.

15 Levey AS, Stevens LA, Schmid CH, et al. A new equation to estimate glomerular filtration rate. Ann Intern Med 2009;150:604-12.

16 Group. KDIGOKAKIW. KDIGO clinical practice guidelines for acute kidney injury. Kidney Int 2012;2:1-138.

17 Pfortmueller CA, Uehlinger D, von Haehling S, et al. Serum chloride levels in critical illness-the hidden story. Intensive Care Med Exp 2018;6:10.

18 Schmidlin O, Tanaka M, Sebastian A, et al. Selective chloride loading is pressor in the stroke-prone spontaneously hypertensive rat despite hydrochlorothiazide-induced natriuresis. J Hypertens 2010;28:87-94.

19 Take C, Ikeda K, Kurasawa T, et al. Increased chloride reabsorption as an inherited renal tubular defect in familial type II pseudohypoaldosteronism. N Engl J Med 1991;324:472-6.

20 Boegehold MA, Kotchen TA. Importance of dietary chloride for salt sensitivity of blood pressure. Hypertension 1991;17:1158-61.

21 Sparks MA, Crowley SD, Gurley SB, et al. Classical renin-angiotensin system in kidney physiology. Compr Physiol 2014;4:1201-28.

22 Wilcox CS. Regulation of renal blood flow by plasma chloride. J Clin Invest 1983;71:726-35.

23 Chowdhury AH, Cox EF, Francis ST, et al. A randomized, controlled, double-blind crossover study on the effects of 2 - $L$ infusions of $0.9 \%$ saline and plasma-lyte $® 148$ on renal blood flow velocity and renal cortical tissue perfusion in healthy volunteers. Ann Surg 2012;256:18-24.

24 Walker HK. The Origins of the History and Physical Examination. In: Walker HK, Hall WD, eds. Clinical methods: the history, physical, and laboratory examinations. Boston, 1990.

25 Ahmad MS, Wahid A, Ahmad M, et al. Prevalence of electrolyte disorders among cases of diarrhea with severe dehydration and correlation of electrolyte levels with age of the patients. J Coll Physicians Surg Pak 2016;26:394-8.
26 Greenberg A. Diuretic complications. Am J Med Sci 2000;319:10-24.

27 Hanberg JS, Rao V, Ter Maaten JM, et al. Hypochloremia and diuretic resistance in heart failure: mechanistic insights. Circ Heart Fail 2016;9:e003180.

28 Haines RW, Kirwan CJ, Prowle JR. Managing chloride and bicarbonate in the prevention and treatment of acute kidney injury. Semin Nephrol 2019;39:473-83.

29 Oh TK, Jeon Y-T, Sohn H, et al. Association of perioperative hyperchloremia and hyperchloremic metabolic acidosis with acute kidney injury after craniotomy for intracranial hemorrhage. World Neurosurg 2019;125:e1226-40.

30 Toyonaga Y, Kikura M. Hyperchloremic acidosis is associated with acute kidney injury after abdominal surgery. Nephrology 2017;22:720-7.

31 Thongprayoon C, Cheungpasitporn W, Cheng Z, et al. Chloride alterations in hospitalized patients: prevalence and outcome significance. PLoS One 2017;12:e0174430.

32 Yunos Nor'azim Mohd, Bellomo R, Hegarty C, et al. Association between a chlorideliberal vs chloride-restrictive intravenous fluid administration strategy and kidney injury in critically ill adults. JAMA 2012;308:1566-72.

33 Van Regenmortel N, Verbrugghe W, Roelant E, et al. Maintenance fluid therapy and fluid creep impose more significant fluid, sodium, and chloride burdens than resuscitation fluids in critically ill patients: a retrospective study in a tertiary mixed ICU population. Intensive Care Med 2018;44:409-17.

34 Krajewski ML, Raghunathan K, Paluszkiewicz SM, et al. Meta-analysis of high- versus low-chloride content in perioperative and critical care fluid resuscitation. Br J Surg 2015;102:24-36.

35 Soussi S, Ferry A, Chaussard M, et al. Chloride toxicity in critically ill patients: what's the evidence? Anaesth Crit Care Pain Med 2017;36:125-30.

36 Semler MW, Self WH, Wanderer JP, et al. Balanced crystalloids versus saline in critically ill adults. N Engl J Med 2018;378:829-39.

37 Self WH, Semler MW, Wanderer JP, et al. Balanced crystalloids versus saline in Noncritically ill adults. N Engl J Med 2018;378:819-28. 